Check for updates

The BMJ

Cite this as: $B M J 2020 ; 370: m 3508$

http://dx.doi.org/10.1136/bmj.m3508

Published: 08 September 2020

\section{Covid-19: Doctors call for action after patients are left unable to get tests}

Abi Rimmer

The BMA has called on the government to "get a grip" on the covid-19 testing system, after the service’s leader revealed that laboratories were at a "critical pinch-point."

Writing on Twitter, Sarah-Jane Marsh, director of testing at NHS Test and Trace, apologised to patients who were unable to get a covid-19 test. $^{1}$

"All of our testing sites have capacity, which is why they don't look overcrowded, it's our laboratory processing that is the critical pinch-point. We are doing all we can to expand quickly," she wrote. "We have additional NHS, Lighthouse, university and partner labs all due to open up imminently and we are also expanding the use of non-laboratory based tests.

"The testing team [is working] on this 18 hours a day, seven days a week. We recognise the country is depending on us."

Chaand Nagpaul, BMA council chair, said that Marsh's admission underlined the "urgent need for the government to get a grip on the testing system that is clearly not delivering." He said that the association had heard reports from doctors that they or their patients had been unable to access tests and follow-up results.

Nagpaul warned, “An effective test and trace system is crucial in managing our response and reducing case numbers, and if people cannot get tested then there is no way of identifying local outbreaks and minimising community spread.

"We also know that the workload of public health staff is becoming increasingly unmanageable-and these professionals are vital in tracing contacts once someone tests positive."

\section{Tests far from home}

Nagpaul also questioned why, if local test sites had capacity as Marsh had indicated, some patients were being sent long distances to get tested.

On Twitter, ${ }^{2}$ Helen Hayes, Labour MP for Dulwich and West Norwood, revealed that one of her constituents had been advised to attend a walk-through testing service in St Andrews, Scotland, 355.8 miles from the constituent's home. "Cases are going up and testing couldn't be more important in stopping further spread. This is utterly unacceptable,” said Hayes.

David Lammy, Labour MP for Tottenham, shared a similar story. "A constituent has just got in touch upset that the nearest drive-through covid test a pupil in Tottenham has been offered is in Inverness," ${ }^{3}$ he tweeted. "The result is they are being kept home from school. This is bonkers. The government needs to quickly explain and fix its approach to testing."

Other Twitter users have also reported being offered a test far from home ${ }^{4}$ or simply being told that the testing service was unavailable. ${ }^{5}$

Nagpaul questioned whether this approach was a "strategy to reduce demand to meet overall lab capacity." If that was the case, he said, it was "completely unacceptable and disproportionately impacts people from lower income backgrounds who can ill afford to travel such distances ... The government must provide an urgent update on how it plans to address this failure that seriously threatens England's ability to reduce the spread of this deadly virus."

Speaking in the House of Commons on 8 September, England's health secretary, Matt Hancock, referred to "next generation tests" such as saliva tests and "rapid turnaround tests that can deliver results in just 20 minutes."

He added, "We are rolling out these tests right now and plan to use them to relieve capacity constraints, to expand asymptomatic testing to find the virus and to give people the confidence that a negative result brings."

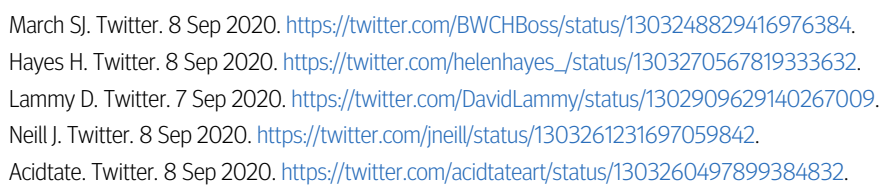




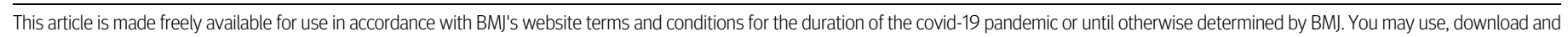
print the article for any lawful, non-commercial purpose (including text and data mining) provided that all copyright notices and trade marks are retained. 